\title{
JEJAK RELIGI PADA MAKAM GERALD ALFRED CUP DI PERKEBUNAN KINA CINYIRUAN MASA KOLONIAL
}

\section{Religious Track on The Tomb of Gerald Alfred Cup in Cinyiruan Plantation of Chincona at Colonial Era}

\author{
Lia Nuralia \\ Balai Arkeologi Jawa Barat \\ Jalan Raya Cinunuk Km. 17, Cileunyi, Bandung, Indonesia \\ E-mail: liabalar@yahoo.com
}

\author{
Naskah diterima: 8 Agustus 2021 - Revisi terakhir: 3 November 2021 \\ Disetujui terbit: 3 November 2021 - Tersedia secara online: 17 November 2021
}

\begin{abstract}
Cinyiruan Plantation of Chinchona has become part of the garden (afdeeling) of the Kertamanah Plantation. Traces of the Cinyiruan Plantation culture can still be traced, one of which is the tomb of Gerald Alfred Cup. What and how the existence of the tomb is the main problem in this paper. The research method used is desk research with a historical approach. The results obtained are that the tomb of Gerald Alfred Cup shows traces of Christian religion in the Cinyiruan Plantation of Chinchona, and the tolerant religious life on the plantations during the colonial period. Traces of religion based on the shape of the tomb marker and European (Dutch) name on tomb inscription. Gerald Alfred Cup or Tuan Keup is a Dutch, plant expert and the last Cinyiruan Plantation of Chinchona of Administrator. The tolerant religious life in the plantations is indicated by the traces of the tomb as an indication of the existence of Christianity and the presence of mosques in the settlements of the workers. The plantation workers are the original indigenous people of the local village who are mostly Muslim.
\end{abstract}

Keywords: Traces of Religion, Tomb of Gerald Alfred Cup, Cinyiruan Plantation of Chinchona

\begin{abstract}
Abstrak
Perkebunan Kina Cinyiruan sekarang ini telah menjadi bagian kebun (afdeeling) dari Perkebunan Kertamanah. Jejak budaya Perkebunan Cinyiruan masih dapat ditelusuri, salah satunya makam Gerald Alfred Cup. Apa dan bagaimana keberadaan makam tersebut menjadi permasalahan pokok dalam tulisan ini. Metode penelitian yang digunakan desk research dengan pendekatan sejarah. Hasil yang diperoleh adalah keberadaan makam Gerald Alfred Cup menunjukkan jejak religi di Perkebunan Kina Cinyiruan, berdasarkan bentuk penanda makam dan nama Eropa (Belanda) pada inskripsi makam. Gerald Alfred Cup atau Tuan Keup adalah seorang Belanda, ahli tanaman dan Administratur Perkebunan Kina Cinyiruan yang terakhir. Kehidupan keagamaan yang toleran di perkebunan ditunjukkan dengan adanya penanda makam salib (makam penganut Kristen), dan keberadaan mesjid di pemukiman para pekerja. Para pekerja perkebunan adalah penduduk pribumi asli dari desa setempat yang sebagian besar menganut Agama Islam.
\end{abstract}

Kata Kunci: Jejak Religi, Makam Gerald Alfred Cup, Perkebunan Kina Cinyiruan.

\section{PENDAHULUAN}

Jejak budaya benda di lokasi perkebunan masa kolonial memiliki bentuk dan jenis beragam, mulai dari pabrik, rumah tinggal, kantor, gudang, sekolah, dan bangunan lainnya. Selain bangunan juga ditemukan struktur bangunan berupa makam atau kuburan(Nuralia, dkk 2019). Keberadaan makam di lokasi kebun menunjukkan adanya 
pemukiman atau kehidupan di masa lalu, bisa mejadi bukti penting yang bernilai sejarah tentang pemukiman masa kolonial di perkebunan.

Pemukiman masa kolonial di lokasi kebun sampai sekarang masih ada yang tetap bertahan, karena kesinambungan perusahaan perkebunan masih terus berlanjut. Salah satu lokasi kebun yang masih berkesinambungan adalah bekas Perkebunan Kina Cinyirun yang telah menjadi bagian (afdeeling) dari Perkebunan Kertamanah. Lahan bekas Perkebunan kina Cinyiruan tersebut sebagian sudah menjadi kebun teh dan sebagian lagi menjadi lahan kosong yang belum dialihfungsikan (Nuralia dkk, 2019).

Kebun kina Cinyiruan meninggalkan jejak sejarah sebagai fakta sejarah, terutama berkaitan dengan keberadaan makam Gerald Alfred Cup atau Tuan Keup (Nuralia dkk, 2019). Salah satu fakta sejarah berkaitan dengan keberadaan makan Tuan Keup tersebut adalah kehidupan spiritual (religi) di perkebunan masa Kolonial Belanda, terutama keyakinan yang dianut oleh para pengelola atau pejabat tinggi perkebunan.

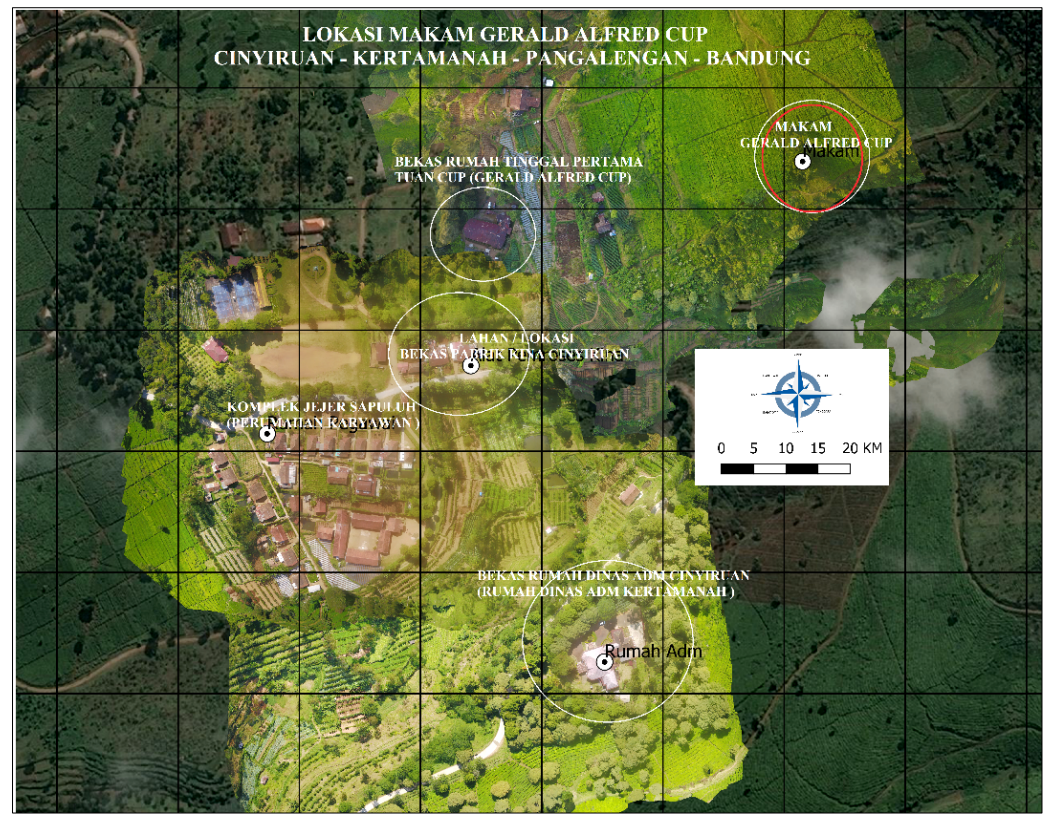

Gambar 1. Lokasi Makam Gerald Alfred Cup (lingkaran merah) Dalam Peta Denah Wilayah Cinyiruan Perkebunan Kertamanah (Sumber: Google Earth \& Foto Udara Drone oleh Irwan Setiawijaya, 2019; modifikasi oleh Lia Nuralia, 2021)

Secara fisik makam Tuan Keup tersebut adalah objek arkeologis atau tinggalan budaya benda (tangible culture) yang memiliki nilai sejarah. Keberadaan Makam Tuan Keup adalah salah satu bukti sejarah otentik tentang kejayaan Perkebunan Kina Cinyiruan di masa lalu, sekaligus berbicara tentang religi masyarakat perkebunan. Masyarakat perkebunan menjadi komunitas hibrid dengan adanya dua budaya yang berbeda dalam satu wilayah pada masa tertentu. Salah satu perbedaan yang tampak adalah perbedaan keyakinan antara pejabat tinggi perkebunan dan para karyawan atau pekerjanya. Sebagian besar pekerja atau karyawan rendahan (buruh kasar) adalah orang pribumi Indonesia asli, dengan keyakinan yang dianut adalah agama Islam. Sementara itu, agama yang dianut para pejabat tinggi perkebunan secara formal adalah agama Kristen. Salah satu ciri menonjol dari makam Kristen adalah penanda makam berbentuk salib atau palang. 
Bentuk tersebut tampak di makam Tuan Keup dengan sedikit penambahan bahan di kemudian hari sehingga tampak samar. ${ }^{1}$

Makam Tuan Keup terletak di pedataran lereng bukit bekas kebun kina, di bawah pohon beringin besar dengan tanaman kina memagarinya (Succirubra dan Ledgeriana). Letak makam tidak jauh dari letak rumah bekas rumah tinggal pribadinya (sekarang menjadi Rumah Dinas Asisten Afdeling Kebun Cinyiruan Perkebunan Kertamanah). Selanjutnya apabila menurun ke lahan lebih rendah, ke arah selatan melalui lahan kebun yang berkelok, akan sampai di Rumah Dinas Administratur Perkebunan Kertamanah (Gambar 1). Dahulu rumah tersebut merupakan Rumah Dinas Administratur Perkebunan Cinyiruan yang kedua ${ }^{2}$ dan pernah ditinggalinya, ketika menjadi administratur Perkebunan Cinyiruan di awal kemerdekaan Indonesia sampai ia meninggal di tahun 1970-an (Nuralia dkk, 2019).

Keberadaan makam Tuan Kap, makam seorang Belanda di perkebunan menjadi jejak budaya penting untuk mengungkap kehidupan spiritual atau religi di perkebunan masa Kolonial Belanda. Apa dan bagaimana jejak religi pada makam Belanda yang ditemukan di bekas kebun kina Cinyiruan, akan menjadi permasalahan pokok dalam tulisan ini. Oleh karena itu, tulisan ini akan mengungkap tentang jejak religi pada makam Tuan Keub di bekas lahan Perkebunan Kina Cinyiruan (Kebun Afdeling Cinyiruan Perkebunan Kertamanah).

Tulisan ini bersumber kepada laporan hasil penelitian tentang perkebunan kina di tahun 2019. Metode yang digunakan dalam kajian ini adalah desk research. Metode penelitian yang digunakan ketika penelitian di tahun 2019 adalah metode penelitian arkeologi dengan pendekatan sejarah. Metode penelitian arkeologi terdiri dari tiga tahap, yaitu pengumpulan data (observasi), pengolahan data (deskripsi), dan penafsiran data (interpretasi) (Deetz, 1967). Pengumpulan data dilakukan melalui studi literatur, wawancara (oral history interviews), dan arsip kolonial. Kemudian pendekatan sejarah dilakukan dengan menggunakan sumber data sekunder berupa arsip kolonial (dokumen lama, foto lama, peta lama). Selanjutnya tahap deskripsi dan analis dilakukan dalam empat langkah sebagai berikut.

1. Dekripsi fisik makam;

2. Deskripsi inskripsi penanda makam atau batu nisan;

3. Analisis; dan

4. Interpretasi.

Tulisan tentang makam kuno zaman kolonial atau Makam Belanda atau makam orang-orang Belanda yang pernah tinggal di Indonesia, sudah cukup tersedia. Salah satunya tulisan Lia Nuralia yang pernah dipublikasikan dalam jurnal nasional terakreditasi, Kapata Arkeologi. Tulisan tersebut berjudul "Traces of the History of South Cisarua Plantation: Archives and Inscription of the Dutch Tomb in Kebon Jahe CisaruaBogor, Jawa Barat" (Nuralia, 2018) akan menjadi salah satu referensi utama. Tulisan ini menjelaskan tentang keberadaan komplek makam keluarga Bik (nama keluarga), sebagai keluarga Eropa (Belanda) merupakan pemilik dan pendiri Perkebunan Teh Cisarua Selatan di masa lalu.

\footnotetext{
${ }^{1}$ Menurut informasi Pak Ramdhan (Bagian Administrasi Kantor Induk Perkebunan Kertamanah), tanda salib di Makam Tuan Kap dimodifikasi bentuknya dengan semen, untuk menghargai karyawan kebun dan penduduk setempat yang hampir $100 \%$ beragama Islam. Juga supaya ada perhatian dan penjagaan dari penduduk sekitar untuk kelestarian keberadaan makam tesebut.

${ }^{2}$ Rumah Tuan Keub yang pertama kali didirikan sekarang berfungsi sebagai Rumah Dinas Asisten Afdeling Cinyiruan Perkebunan Kertamanah. Rumah tersebut terletak tidak jauh dari makamnya sekarang.
} 
Tulisan tentang makam kuno Belanda juga pernah mejadi satu skripsi yang pernah dikeluarkan oleh Fakultas Ilmu Budaya Universitas Indonesia. Kemudian skripsi tersebut dipublikasikan juga menjadi satu arikel yang berjudul "Teks pada Batu Nisan Baron Van Imhoff Dilihat melalui Analisis Semiosis Model Peirce dan Danesi-Perron" oleh Lilie Suratminto. Kedua artikel tersebut merupakan contoh dari beberapa artikel tentang makam kuna Belanda lainnya.

Makam menjadi petunjuk adanya kehidupan manusia masa lampau di suatu daerah tertentu dengan lingkungan yang tertentu pula. Keberadaan makam juga akan menjadi penunjuk tentang kehidupan spiritual atau kehidupan keagaaman atau religi satu atau sekelompok orang, tokoh atau masyarakat biasa dan atau keduanya. Dengan demikian, akan dijelaskan terlebih dahulu pengertian tentang makam dan religiMakam berarti kuburan atau pekuburan (Kamus Besar Bahasa Indonesia). Makam orang Belanda atau Eropa lainnya di Indonesia (Jawa) dikenal sebagai kerkhoff (bahasa Belanda), berasal dari kata kerk yang berati gereja dan hoff yang berarti halaman, sehingga kerkhoff berati halaman gereja. Ketika itu tradisi orang Belanda mayoritas Kristen akan menguburkan keluarganya di samping atau di halaman atau di taman gereja (Nuralia, 2018). Pengertian kerkhoff berkembang menjadi istilah umum untuk kuburan atau pemakaman. Gereja di Jawa tidak lagi memiliki halaman yang luas, sehingga tidak bisa menampung banyak orang meninggal untuk dimakamkan di taman gereja tersebut. Keadaan ini membuat makna kerkop melebar menjadi pemakaman, baik makam yang ada di halaman gereja maupun di luar gerea, bahka tambah meluas melintas batas etnis dan agama. Bukan hanya pemakaman orang-orang Belanda yang disebut kerkhoof, tetapi juga pemakaman orang-orang Cina (Rusyanti, 2015).

Pengertian religi pada umumnya dimaknai sebagai agama yang dianut oleh seseorang atau sekelompok orang. Religi berasal dari kata re dan ligare yang berarti menghubungkan kembali yang telah terputus, yaitu hubungan antara Tuhan dan manusia yang telah terputus oleh dosa-dosanya (Mubarok, 2003: 45). Religi mengandung unsur internalisasi agama dalam diri individu. Religi merupakan penghayatan terhadap agama dengan ketaatan menjalankan ibadah ritual, keyakinan, pengamalan, dan pengetahuan agama yang dianutnya (Ancok, D \& Suroso, 2008).

Konsep religi atau agama secara umum merupakan sistem nilai keyakinan kepada Tuhan, yang memiliki aturan-aturan dan kewajiban-kewajiban yang harus dipatuhi oleh pemeluknya. Ajaran agama adalah hubungan antara Khalik (Tuhan) dan Mahkluk yang berwujud dalam ibadah, yang dilakukan dalam sikap keseharian (Gufron, M. Nur, 2010).

\section{HASIL DAN PEMBAHASAN}

Ketika melakukan penelitian di tahun 2019, kondisi makam Tuan Keup cukup memprihatinkan, karena tampak tidak terurus dan terabaikan. Makam tertutup rumput ilalang dan sebaran daun-daun kering turut menumpuk dan memenuhi ruang sekeliling makam (Gambar 2). Kemudian di tahun 2021 keadaan makam dan lingkungannya menjadi lebih baik. Perhatian pihak Perkebunan Kertamanah khususnya dan penduduk di sekitar perkebunan, membuat kondisi makam tampak lebih rapih dan terawat. Makam tampak jelas dan bersih dengan rumput yang sudah dibersihkan dengan rapih dan tumpukan daun kering di atasnya sudah tidak menutupi jirat makam (Gambar 3)

Gerard Alfred Cup dikenal sebagai salah seorang ahli dan pengembang tanaman kina (botanis) di Perkebunan Cinyiruan. Para kolega dan keluarga mengenalnya sebagai seorang pengusaha perkebunan di tanah Priangan dahulu, dan menjadi pimpinan tertinggi atau administratur terakhir di Perkebunan Kina Cinyiruan. 


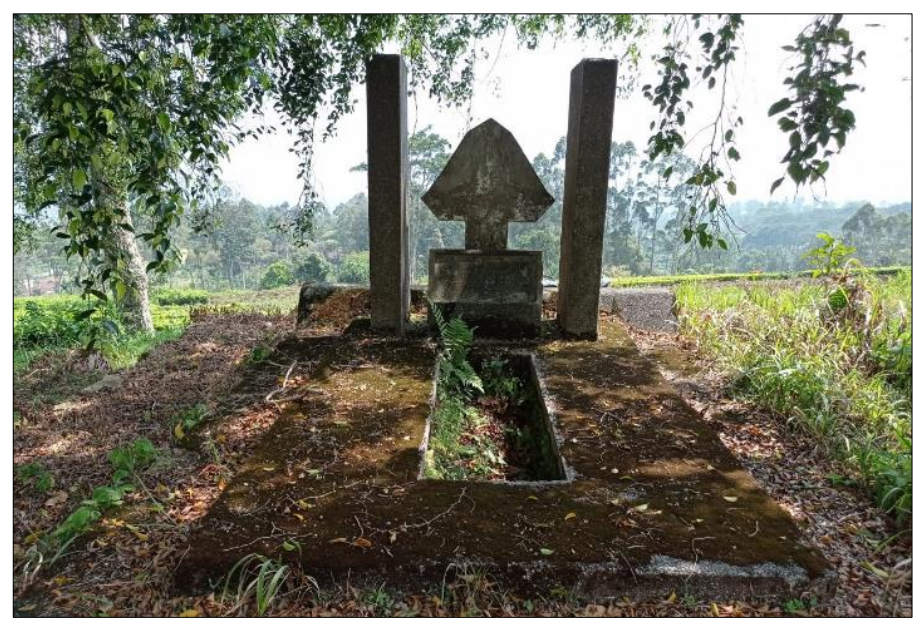

Gambar 2. Makam Gerald Alfred Cup (Tuan Cup) di Bekas Lahan Kebun Kina Cinyiruan (Perkebunan Kertamanah) Pangalengan - Bandung (Dok. Ramdhan Kertamanah, 2021)

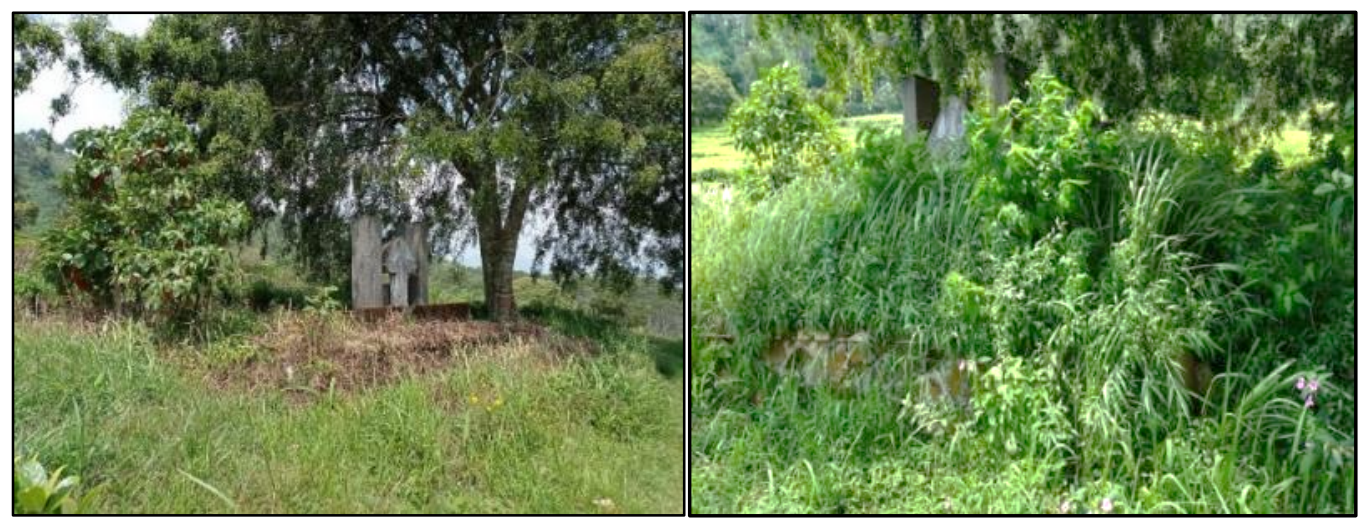

Gambar 3. Makan Tuan Cup tertutup rumput ilalang di bekas Kebun Kina Cinyiruan (Dok. Balai Arkeologi Jawa Barat, 2019)

Perkebunan Kina Cinyiruan pertama kali didirikan di tahun 1855 oleh Pemerintah Hindia Belanda, dan kini telah menjadi kenangan karena kebun kina Cinyiruan sudah tidak ada lagi dan produksi kina bukan lagi sebagai salah satu komoditas unggulan PTPN VIII. Areal bekas Perkebunan Kina di Cinyiruan di tahun 2021 ini masih bisa ditelusuri, tetapi sudah tidak ditemukan lagi tanaman kinanya. Terakhir di tahun 2019, tanaman kina (Cinchona-succirubra dan Cinchona-ledgeriana) masih ada. Sebagian lahan bekas kebun kina sudah menjadi kebun teh, sebagian lagi menjadi lahan kosong atau dibiarkan begitu saja. Sementara itu, bekas pabrik pengolahan kina Cinyiruan tinggal sisa pondasi batu, yang di atasnya sudah berdiri rumah karyawan dan Posyandu Aster 21. Areal Kebun Kina Cinyiruan sekarang telah menjadi bagian kebun (afdeeling) dari Perkebunan Kertamanah PTPN VIII, yang bergabung sejak tahun 1970-an. 


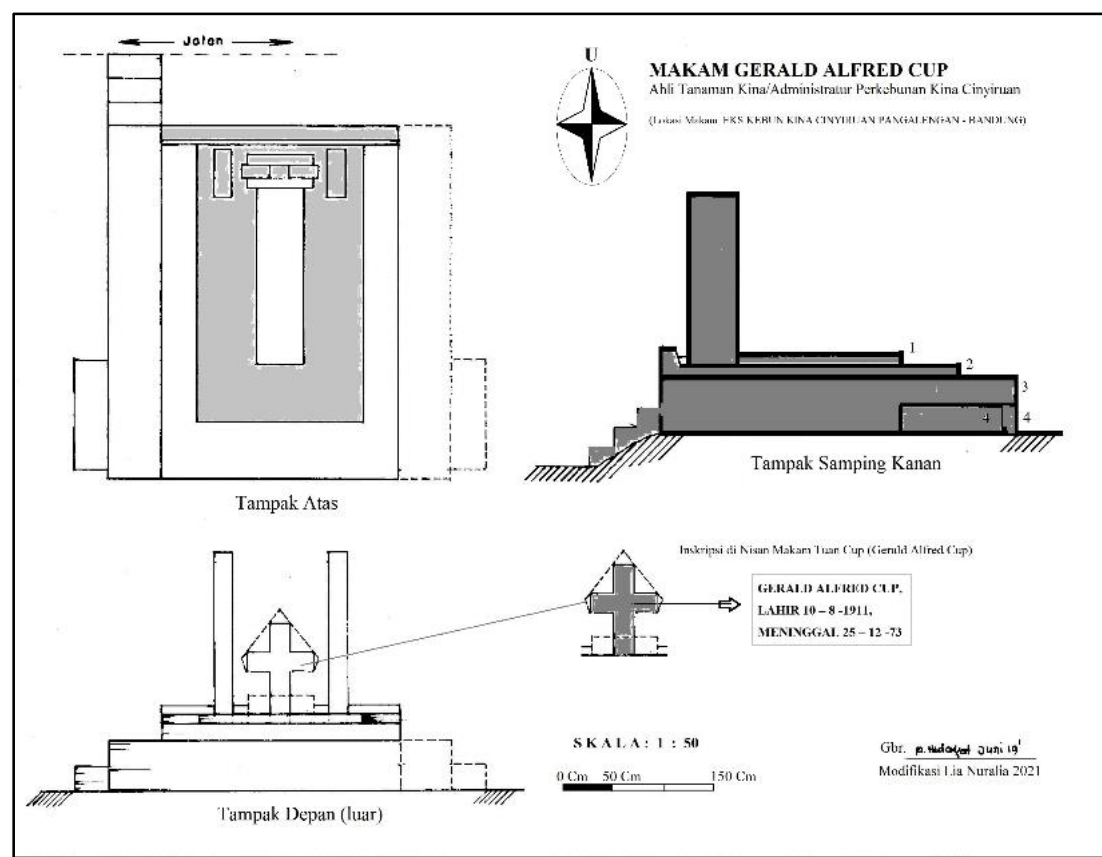

Gambar 4. Bentuk Makam Tuan Cup Dalam Lukisan Tangan (Gambar: Dayat Hidayat, 2019. Dok. Balai Arkeologi Jawa Barat, 2019)

Makam orang Belanda di Indonesia menjadi perhatian karena secara fisik bentuknya berbeda dengan makam atau kuburan orang Indonesia kebanyakan. Wujud fisik tampak dari bahan batu nisan dan penanda nisan serta orientasi atau arah makam (Gambar 4). Penanda makam menjadi yang utama, yang menunjukkan keyakinan yang dianut dan kedudukan atau status sosial orang yang dimakamkan tersebut. Kemudian keletakan makam apakah berada di pemakaman umum atau pemakaman keluarga atau lahan khusus juga memberi petunjuk atau makna lain keberadaan makam tersebut.

Makam Tuan Keup ditemukan di area bekas Kebun Kina Cinyiruan memiliki wujud fisik yang unik dan terletak di lahan khusus. Secara fisik dapat dideskripsikan sebagai berikut.

1. Bentuk makam: persegi panjang;

2. Orientasi arah makam: timur-barat (letak penanda makam ada di barat);

3. Bentuk dan bahan penanda makam/nisan: salib diapit dua batu tegak vertikal terbuat dari batu alam;

4. Bentuk dan bahan jirat makam: persegi panjang berundak/berteras 3 tingkatan. Pada tingkatan pertama terdapat tangga naik 3 anak tangga di bagian muka, samping kanan dan samping kiri makam;

5. Inskripsi pada penanda makan bertuliskan nama, tanggal lahir, dan tanggal meninggal, yaitu Gerarld Alfred Cup, Lahir 10-8-1911, Meninggal 25-12-73;

6. Nama tertulis Gerarld Alfred Cup, seharusnya Gerald Alfred Cup. Kesalahan sedikit huruf "r" pada "Gerarld" yang seharurnya "Gerald" diperkirakan sebagai kesalahan pembuat inskripsi;

7. Lingkungan makam terletak di bawah pohon Beringin di pedataran lereng bekas Kebun Kina; dan

8. Makam Tuan Keup hanya satu makam saja dan di sekitarnya tidak ditemukan makam lainya. 

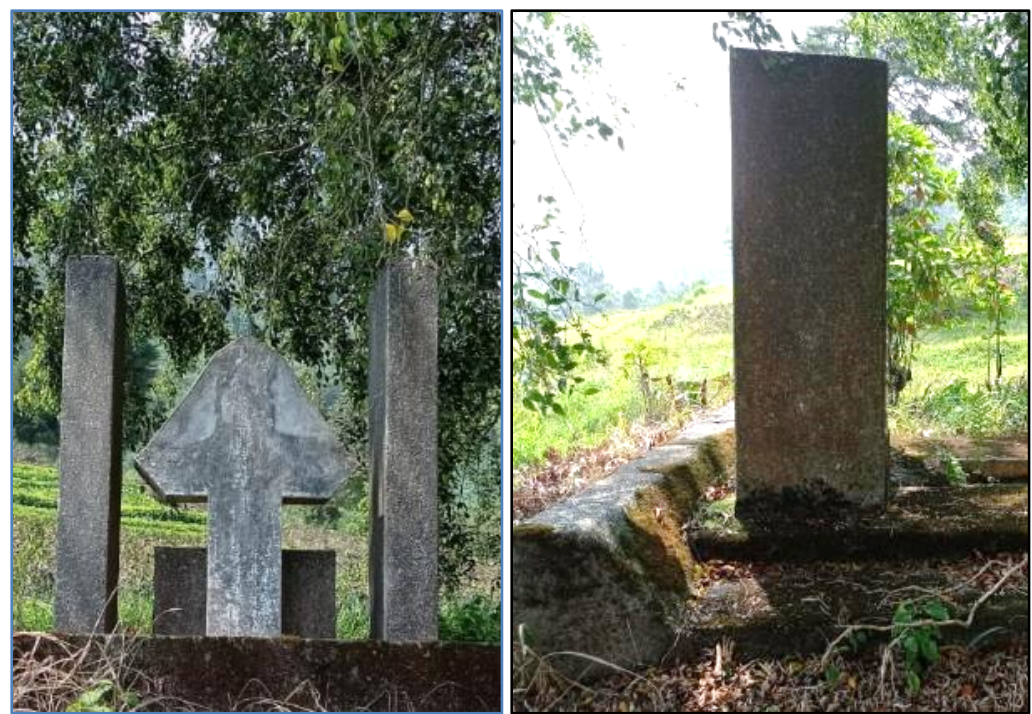

Gambar 5. Penanda Makam Gerarld Alfred Cup Tampak Depan dan Samping (Cinyiruan - Kertamanah - Pangalengan - Bandung) (Dok. Ramdhan Kertamanah, 2021)

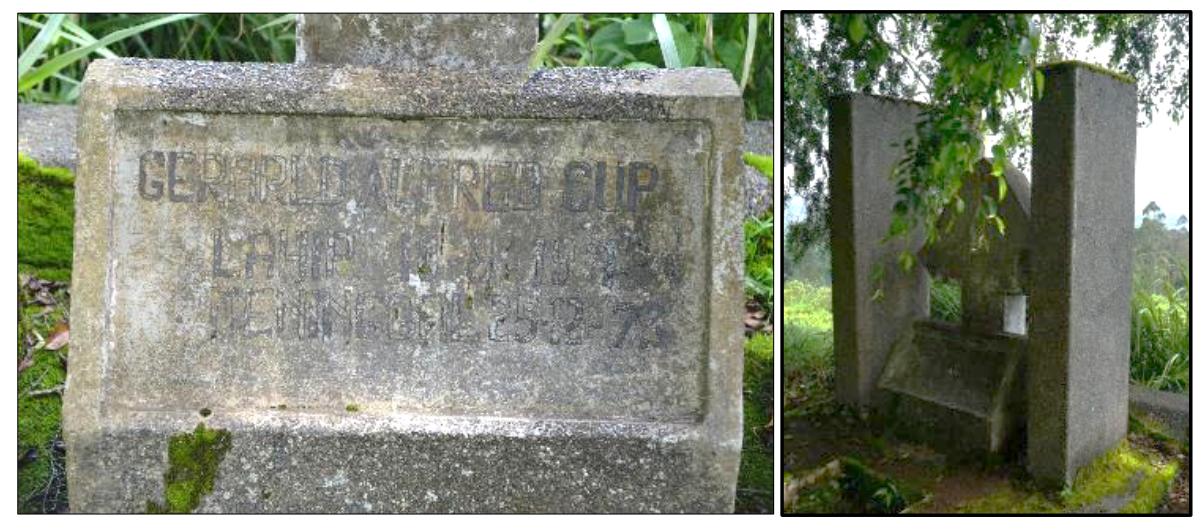

Gambar 6. Inskripsi Pada Penanda Makam (Batu Nisan) Berbunyi "Gerarld Alfred Cup, Lahir 10-8-1911, Meninggal 25-12-73” (Dok. Balai Arkeologi Jawa Barat, 2019)

Pemakaman Belanda umumnya secara fisik tampak menonjol dengan kemegahan bentuk batu nisan dan hiasan makam, dibandingkan dengan pemakaman pribumi Indonesia ketika itu. Pemakaman memiliki makna sebagai tempat menguburkan jasad orang meninggal, serta sebagai persembahan yang meninggal sendiri, keluarga yang ditinggalkan, dan kerabat lainnya (Nuralia, 2018: 2)(Nuralia, 2018). Kemudian di dalam budaya Barat, penanda makam atau batu nisan berisi informasi penting dari orang yang dimakamkan. Di antaranya peran orang yang dimakamkan semasa hidupnya, kumpulan tulisan kenang-kenangan (festschrift) atau liber decorum (buku kenang-kenangan) berisi tulisan dari teman-teman dekat, ketika seseorang menjalani sisa hidupnya berkaitan dengan kesenangan dan status/jabatannya. Biasanya yang dituliskan adalah tema yang paling disukai oleh orang yang meninggal tersebut (Suratminto, n.d.).

Berdasarkan pengertian dan makna makam Belanda tersebut, wujud fisik makam Tuan Keup berbeda dari makam-makam penduduk setempat dan karyawan perkebunan lainnya, dilihat dari penanda makam tanda salib dan letak makam di atas ketinggian, dan hanya satu makam saja atau tanpa ada makam lainnya. Apabila dibandingkan dengan makam Belanda umumnya, makam Tuan Keup tampak sederhana tanpa ornamen atau hiasan atau penggunaan bahan yang mewah. Demikian juga inskripsi pada makam hanya 
identitas nama, tanggal lahir, dan tanggal meninggal. Tidak ada kata-kata persembahan atau pernyataan dari pihak keluarga atau kerabat atau sahabat sebagai kenang-kenangan atau tanda cinta kasih. Keadaan tersebut menunjukkan informasi yang ditampilkan hanya berita singkat saja. Inskripsi tertulis ini merupakan data verbal berisi informasi penting keberadaan makam, sedangkan data nonverbal dijumpai pada simbol-simbol yang digunakan berupa ragam hias makam (Nuralia, 2018).

Kesederhanaan bentuk makam Tua Keup tersebut diperkirakan karena ketika dia meninggal sudah memasuki era Negara Kesatuan Republik Indonesia (tahun 1970). Kemudian status sosial orang Belanda ketika tahun 1970-an tidak sama dengan ketika masa kolonial, telah terjadi pergeseran pandangan yang cukup tegas dan tajam. Pandangan terhadap orang Belanda dengan kolonialisme dan imperialisme nya yang telah selesai di muka bumi Indonesia. Pandangan negatif tentang buruknya penjajahan dan kejamnya kaum penjajah. Pandangan Tuan Kulit Putih yang telah menjadi sumber kemiskinan dan keterbelakangan anak-anak jajahan yang beretnis pribumi asli Indonesia di daerah koloni. Beberapa pandangan tersebut sangat tendesius dan penuh semangat nasionalisme tinggi dalam perspektif ke-Indonesia-an. Akan tetapi, satu hal yang diperkirakan objektif dan masuk akal adalah ketika Tuan Keup meninggal dunia tidak ada keluarga dekat yang mendampinginya. Dia diurus dan dimakamkan oleh para pekerja perkebunan yang setia dan hormat padanya, karena segala kebaikan dan peran pentingnya di masa lalu. Oleh kerena, inskripsi yang terpahat di penanda makam hanya yang paling mendasar saja. Inskripsi yang pada masa sekarang menjadi prasasti kolonial yang bernilai sejarah dan dapat memberi bukti penting tentang Perkebunan Kina Cinyiruan di masa lalu dan masa kini.

Pada sekitar abad ke-5 Masehi, istilah prasasti awalnya merujuk kepada sumber sejarah kuna yang ditulis di batu atau logam. Sebagian prasasti dibuat berdasarkan perintah raja atau penguasa suatu wilayah, berisi keputusan pengadilan (jayapattra), penetapan daerah sebagai Sima (daerah bebas pajak) untuk pemeliharaan bangunan suci tertentu (Buchari., 1985). Pengertian prasasti secara lebih sederhana adalah artefak yang ditulisi, yang berisi informasi masa lalu (Susanti, 2005: 1)(Susanti, 2005). Inskripsi atau prasasti di makam Belanda dapat dikatakan sebagai prasasti masa kolonial. Prasasti masa kolonial atau prasasti kolonial berbahasa Belanda atau Eropa lainnya atau bahasa lokal (Melayu, Jawa, Sunda), ditulis dengan huruf Latin, terutama dipahatkan pada makam sebagai penanda kubur atau batu nisan Belanda. Juga terdapat di gereja-gereja, rumah dinas pejabat kolonial, benteng, tugu peringatan, mata uang, cap, dan meriam (Nuralia, 2017).

Demikian juga dengan inskripsi makam Tuan Keup, dapat dikatakan sebagai inskripsi atau prasasti yang mewakili kepentingan pribadi dari keluarga Tuan Kap atau wasiat dari Tuan Keup sendiri. Akan tetapi, mengingat Tuan Keup adalah seorang Administratur Perkebunan Kina Cinyiruan, diperkirakan pembuatan inskripsi merupakan pemghargaan dari pihak perusahaan perkebunan dan menjalankan wasiat pribadi Tuan Keup sendiri akan kecintaannya terhadap kebun kina dan lingkungannya. ${ }^{3}$

Makan Tuan Keup memiliki inskripsi atau prasasti kolonial sebagai artefak yang dapat memberi informasi tentang identitas diri dan kehidupan masyarakat perkebunan secara umum. Inskripsi pada makam ini ada data verbal berupa nama, tanggal lahir, dan

\footnotetext{
${ }^{3}$ Menurut keterangan Pak Jajang (Asisten Afdeling Tirtasari Perkebunan Kertamanah), Tuan Kapa tau Tua Keub pernah berwasiat apabila meninggal ingin dimakamkan di kebun kina Cinyiruan, yang menjadi kecintaannya terhadap kebun kina Cinyiruan dan daerah Pangalengan umumnya (Kebun CinyiruanKertamanah, Juni 2019).
} 
tanggal meninggal. Kemudian ada data nonverbal yang berisi simbol-simbol tertentu tanpa ragam hias atau ornamen makam. Data nonverbal berupa bentuk penanda makamnya adalah tanda Salib.

Nama yang tertera di penanda makam tersebut adalah Gerald Alfred Cup. Nama seperti itu pada masa kolonial selalu diidentikkan sebagai nama orang Eropa (Belanda), berkulit putih, seorang penguasa atau penjajah, pejabat atau pengusaha, orang kaya dan memiliki status sosial tinggi, golongan/kelas pertama dalam stratifikasi sosial penduduk Hindia Belanda ketika itu ${ }^{4}$, serta beragama Kristen. Nama tersebut menjadi data verbal yang memberi penjelasan tentang identitasnya dan kehidupan keagamaan di perkebunan secara umum. Data verbal ini menjadi jejak religi yang kuat yang ditemukan dalam komunitas khusus, kehidupan sosial (agama) masyarakat perkebunan masa kolonial.

Penanda makam dengan tanda salib pada makam Tuan Keup menjadi petunjuk utama tentang keyakinan yang dianutnya. Tuan Kap seorang Nasrani atau menganut agama Kristen. Keyakinan yang menjadi berbeda dengan para karyawan yang berasal dari golongan pribumi, yang mayoritas bergama Islam. Kenyataan tersebut menunjukkan kedua agama hidup dalam ruang dan waktu yang sama, serta menggambarkan sikap religiusitas yang toleran. Satu sama lain saling menghargai dan tidak saling memaksanakan kehendak.

Penanda makam atau batu nisan makam Belanda merupakan tinggalan budaya materi (tangible culture), bisa dijadikan bukti sejarah tentang keberadaan perkebunan di masa lalu. Batu nisan makam memiliki fungsi sebagai tanda adanya jenazah yang dikuburkan di suatu tempat (Ambary, 1998). Keberadaan makam Tuan Keup dengan batu nisan atau penanda makam bentuk salib, merupakan benda budaya yang menjelaskan tentang jenazah yang dimakamkan beragama Kristen. Kemudian letak makam berada di area bekas kebun kina sudah dipastikan bahwa pada zaman dahulu Perkebunan Kina Cinyiruan pernah ada dan pernah jaya pada masanya.

Keberadaan makam Tuan Keup memberi petunjuk tentang religi di perkebunan masa kolonial. Pengaruh agama Kristen terhadap masyarakat perkebunan warisan zaman Hindia Belanda di Priangan sangat minim. Para pekerja perkebunan (pribumi) ketika itu hampir $100 \%$ menganut agama Islam. Pada setiap perumahan para pekerja perkebunan selalu ada sarana ibadah berupa masjid. Kemudian belum pernah ditemukan di emplasemen permukiman perkebunan, bangunan gereja atau jejak arkeologis bekas bangunan gereja. Informasi yang diperoleh adalah diduga gereja kecil pernah ada di dekat rumah pejabat tinggi perkebunan, tetapi jejak arkeologisnya berupa sisa pondasi atau struktur bangunan belum ditemukan, sehingga tidak ada bukti keberadaan gereja.

Sepanjang sejarah kolonialisme di Indonesia, diinformasikan bahwa orang-orang Belanda adalah penganut Protestan yang beraliran Calvinis. Di Maluku sebagian besar penduduk yang telah beragama Katolik berganti menjadi Calvinis. Bagaimana dengan penganut Protestan di perkebunan di Priangan Jawa Barat, juga belum ada sumber data yang dapat menjelaskan keberadaannya.

Orang-orang Belanda hampir sama dengan orang-orang Portugis dalam mensikapi orang-orang pribumi, sebagai penduduk asli daerah koloni. Mereka menaruh perhatian besar terhadap kehidupan penduduk, termasuk kehidupan beragama atau kepercayaan yang dianut penduduk pribumi di daerah koloninya (Snelleman, 1905). Apabila diketahui

\footnotetext{
${ }^{4}$ Stratifikasi Sosial Penduduk Hindia Belanda dibagi menjadi tiga golongan atau tiga kelas sosial, yaitu: (1) kelas atas teridiri dari orang-orang Eropa atau peranakan yang disejajarkan dengan orang-orang Eropa, (2) Kelas menengah terdiri dari orang-orang Timur Asing (Cina, Arab, India), (3) Kelas bawah terdiri dari orang-orang pribumi asli (Indonesia)(van Niel, 1988).
} 
telah ada orang pribumi yang beragama Kristen, akan menjadi perhatian khusus dan tidak akan diabaikan keberadaannya. Kemudian apabila di daerah koloninya belum ada orang pribumi yang menganut Agama Kristen, mereka akan berusaha menyebarkan ajaran Kristiani tersebut di antara penduduk pribumi.

Perhatian terhadap kehidupan keagamaan para koloni di Nusantara sudah dimulai sejak kedatangan mereka. Orang-orang Belanda dengan misi mencari harta kekayaan, sejak berdirinya Verenigde Oost-Indische Compagnie (VOC), juga membawa misi penyebaran agama Kristen. Setelah beralih kepada Pemerintahan Hindia Belanda perhatian pemerintah lebih besar lagi terhadap perkembangan Kristen di daerah koloninya. Pada abad ke-19 terkenal dengan adanya gerakan misionaris atau Era Misi (Age of Missions) (Snelleman, 1905). Lembaga-lembaga misionaris segera dibentuk dan mereka berupaya untuk mengembangkan agama Kristen di kalangan penduduk pribumi, walaupun sesungguhnya bangsa pribumi sudah menganut agama tertentu. Gerakan ini didukung oleh Pemerintah Belanda dengan memberi gaji para pendeta yang aktif menyebarkan dan mengembangkan Agama Kristen di Hindia Belanda (Aritonang, 1985).

Gerakan misionaris Kristen, terutama yang ditujukan kepada penduduk pribumi yang sudah menganut agama Islam memicu reaksi dari kaum pergerakan Muhammadiyah. Reaksi ditunjukkan dengan kehati-hatian dalam berbagai bentuk tindakan. Salah satu tindakan nyata dilakukan di beberapa daerah yang mayoritas penduduknya beragama Islam, dengan menyatakan tertutup untuk gerakan misi tersebut. Selain itu, para misionaris harus memiliki surat keterangan izin dari Pemerintah Hindia Belanda, dalam aksinya menyebarkan dan mengembangkan ajaran Kristen. Pemerintah Hindia Belanda menerapkan kebijakan tersebut untuk menjaga rust en orde (ketertiban dan keamanan) di wilayah koloninya. Pada kenyataannya gerakan misi terus berjalan dan mengalami peningkatan yang signifikan pada abad ke-20 (Aritonang, 1985).

Gerakan misionaris tersebut hampir terjadi di seluruh wilayah Indonesia ketika memasuki abad ke-20. Akan tetapi, keadaan tersebut berbeda dengan di wilayah perkebunan, temasuk Perkebunan Kina Cinyiruan. Gerakan misionaris Kristen tidak menjangkau para pekerja perkebunan, para pemilik dan pengelola perkebunan pun tidak menaruh perhatian terhadap gerakan tersebut. Belum ada sumber data yang menyebutkan tentang penyebaran dan perkembangan agama Kristen di lokasi perkebunan. Keadaan tersebut juga didukung oleh tidak ditemukannya sumber data fisik dan nonfisik (informasi lisan) ketika melakukan penelitian di lokasi perkebunan.

Posisi para pengusaha perkebunan menjadi eksklusif dan tidak tersentuh, seperti halnya keberadaan perkebunan besar masa kolonial, terutama setelah keluarnya UU Agraria 1870, menjadi enclave tersendiri, seperti negara dalam negara (Kartodirdjo dan Djoko Surjo 1991). Keadaan ekslusif tersebut juga menyentuh kehidupan keagamaan di perkebunan, sehingga misi Kristen pun tidak dapat masuk dan menyentuh komunitas perkebunan yang sebagian besar karyawan atau pekerjanya menganut Agama Islam. Keadaan ini bagi para pemilik dan pengusaha perkebunan tidak pernah dipermasalahkan, karena orientasi ekonomi adalah yang utama. Kehidupan keagamaan di perkebunan menunjukkan ketertiban dan keamanan yang sangat terjaga. Jejak religi di perkebunan memberikan bukti tentang keadaan tersebut. 


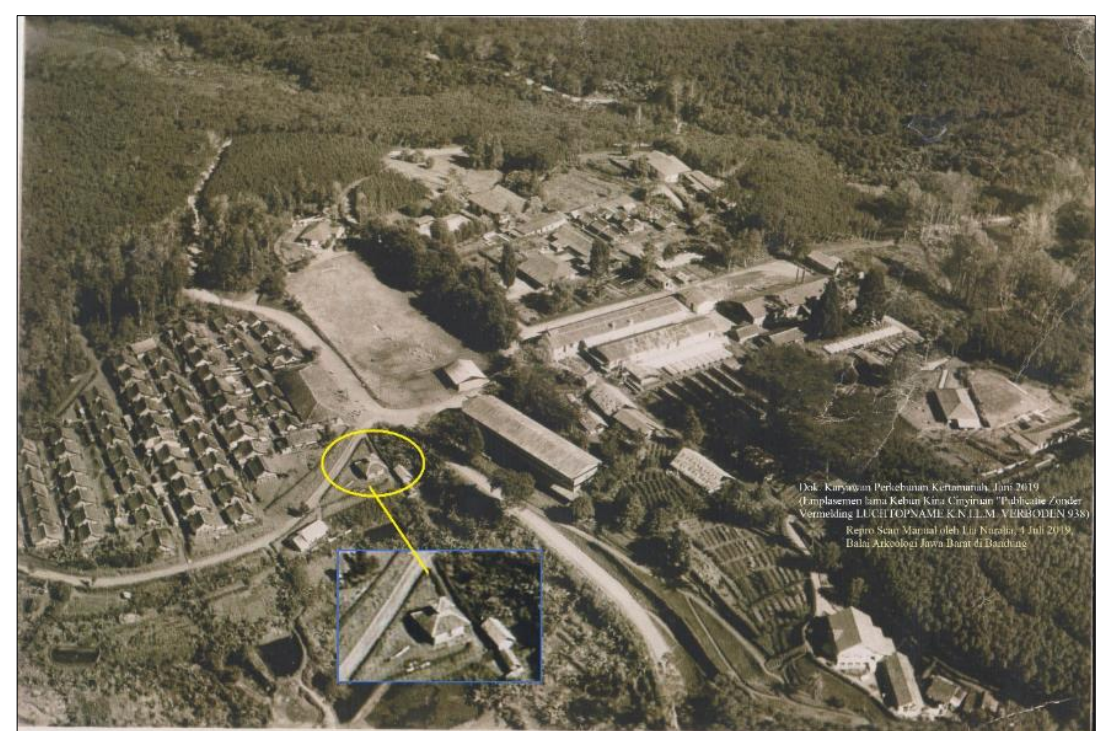

Gambar 8. Mesjid lama Cinyiruan tampak pada foto lama Emplasemen Perkebunan Cinyiruan Masa Kolonial (Sumber: Nuralia dkk, 2019. Modifikasi Lia Nuralia, 2021)

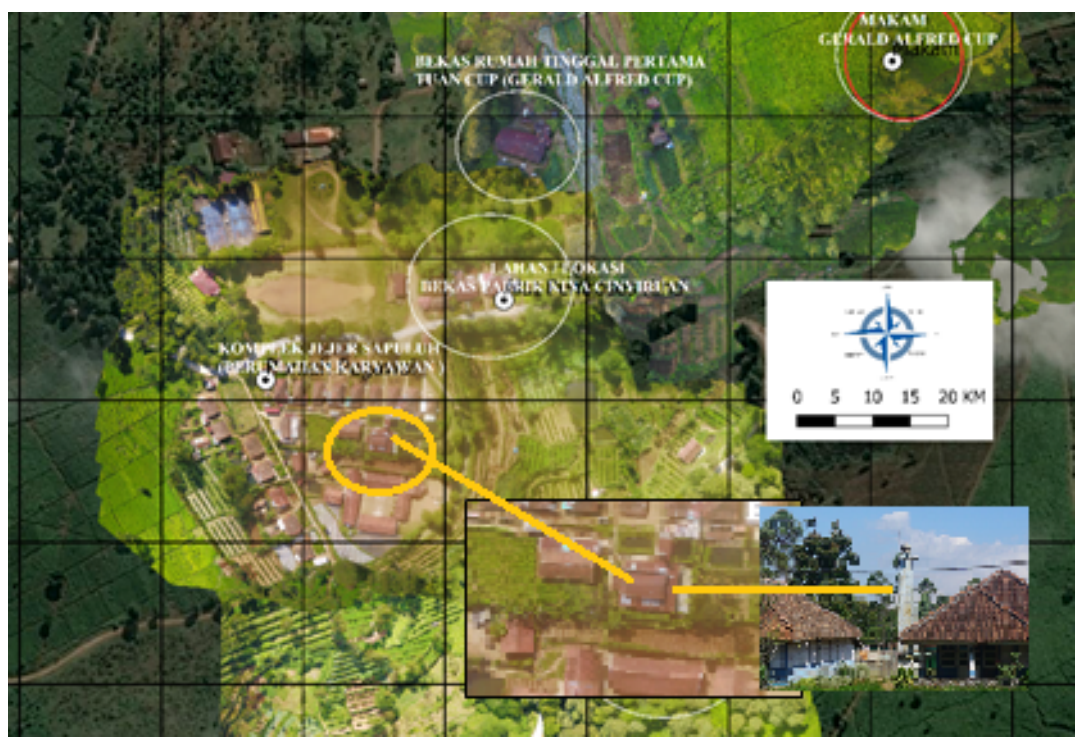

Gambar 9. Mesjid baru Cinyiruan di Perumahan Karyawan Jejer Sapuluh, Afdeling Cinyiruan Perkebunan Kertamanah (Sumber: Nuralia dkk, 2019. Modifikasi Lia Nuralia, 2021)

Keberadaan makam Tuan Keup dan keberadaan bangunan masjid baru atau masjid lama yang sezaman menjadi bukti fisik keadaan tertib dan aman. Bangunan masjid lama sekarang sudah tidak ada, tetapi pernah ada dan dapat dilihar bangunan masjid lama berdiri di dekat lokasi pemukiman para pekerja perkebunan, yaitu emplasemen Permkiman Perkebunan Cinyiruan di masa kolonial (Gambar 8). Bangunan Mesjid Cinyiruan sekarang juga tetap ada, hanya saja lokasi dipindahkan, dari lokasi lama di tepi jalan perkebunan ke lokasi baru di bagian dalam perumahan para karyawan Jejer Sapuluh (Gambar 9).

Keberadaan masjid menunjukkan keyakinan yang dianut komunitas perkebunan sebagian besar adalah Agama Islam. Kemudian jejak adanya penganut agama Kristen 
justru tidak ditunjukkan dengan adanya bangunan Gereja, tetapi keberadaan makam dengan penanda nisan Salib. Kemungkinan tidak ada gereja yang dibangun khusus di perkebunan, tetapi ada gereja di dalam rumah. Dalam hal ini fungsi rumah tidak saja sebagai tempat tinggal, tetapi juga sebagai tempat ibadah (Hidajat, 2018). Sepertinya halnya dalam ajaran Islam, beribadah juga bisa dilakukan di rumah. Mesjid menjadi tempat ibadah secara individu dan secara berjamaah.

Penganut Kristen di perkebunan diperkirakan hanya orang-orang Belanda atau Eropa lainnya, yang berstatus sebagai pemilik dan pengelola perkebunan. Jumlahnya jauh lebih sedikit apabila dibandingkan dengan penganut agama Islam, sehingga dimungkinkan tidak diperlukan membangun gereja sebagai bangunan tersendiri atau cukup beribadah di rumah saja. Kemudian ada kemungkinan juga bahwa para pemilik atau pengelola perkebunan yang beragama Kristen taat melakukan ibadahnya dengan mendatangi gereja yang ada di kota. Dengan demikian, jejak religi di perkebunan masa kolonial bisa ditunjukkan dengan keberdaan makam Belanda dengan penanda makam tertentu. Keberadaa makam Tuan Keup menjadi bukti penting yang menunjukkan jejak religi atau agama Kristen di perkebunan.

\section{SIMPULAN}

Makam Gerald Alfred Cup atu Tuan Keup menjadi bukti sejarah penting tentang kehidupan keagamaan di Perkebunan Kina Cinyiruan pada masa kolonial. Keberadaan makam tersebut menjadi jejak religi (Agama Kristen) satu-satunya yang sudah ditemukan sampai sekarang. Makam tersebut memiliki jirat tiga tingkatan dengan tiga anak tangga yang terletak di bagian depan (barat/penanda makam), samping kiri (utara) dan samping kanan (selatan). Penanda makam (batu nisan) berbentuk Salib, yang sudah mengalami penambahan sehingga bentuknya tampak samar. Bahan jirat dan penanda makam terbuat dari batu alam. Pada penanda makam dipahatkan tulisan atau inkripsi tentang identitas orang yang dimakamkan.

Inskripsi tersebut menunjukkan nama seorang Belanda yang diketahui sebagai ahli tanaman atau botanis sekaligus Administratur terakhir Perkebunan Kina Cinyiruan, sebelum bergabung dengan Perkebunan Kertamanah. Nama yang terpahat pada penanda makam sebagai data verbal dan bentuk Salib penanda makam sebagai data nonverbal, menunjukkan jejak religi Agama Kristen di perkebunan masa kolonial. Selanjutnya menjadi bukti sejarah penting tentang kehidupan kegamaan yang beragam dan sikap toleransi antara pemilik/pengusaha dan pekerja perkebunan.

\section{DAFTAR PUSTAKA}

Ambary, H. M. A. (1998). Menemukan Peradaban, Arkeologi dan Islam di Indonesia. Pusat Penelitian Arkeologi Nasional.

Ancok, D \& Suroso, F. . (2008). Psikologi Islam: Solusi Islam Atas Problem-Problem Psikologi. Pustaka Pelajar.

Aritonang, J. S. (1985). Kiai Sadrach; Riwayat Kristenisasi di Jawa. Grafiti Press.

Buchari. (1985). Epigrafi dan Historiografi Indonesia. In S. Dkk (Ed.), Historiografi Indonesia: Sebuah Pengantar, (pp. 39-57.). Gramedia Pustaka Utama. 
Deetz, J. (1967). Invitation to Archaeology. Natural History Press for The American Museum of Natural History.

Gufron, M. Nur, dan R. R. (2010). , Teori-Teori Psikologi,. Ar-Ruzz Media,.

Hidajat, D. (2018). Gereja di Rumah: Kontekstualisasi Fungsi-fungsi Rumah dalam Masa Perjanjian Baru untuk Pekabaran Injil. Jurnal Veritas, Vol. 17,(No. 2, Desember 2018.), Halaman 107-118.

Kartodirdjo, Sartono, \& D. S. (1991). Sejarah Perkebunan di Indonesia, Kajian Sosial Ekonomi. Aditya Media.

Mubarok, A. (2003). Sunatulloh Dalam Jiwa Manusia, Sebuah Pendekatan Psikologi Islam. The Internationa Institute of Islamic Thought (ITT).

Nuralia, L. (2017). Struktur Sosial dan Nilai-Nilai Kolonial Pada Rumah Pejabat Tinggi Perkebunan Zaman Hindia Belanda di Jawa Bagian Barat. ,. Jurnal Kapata Arkeologi, Vol. 13,(No. 1, Juli 2017.), Halaman 1-20.

Nuralia, L. (2018). Traces of The History of South Cisarua Plantation: Archieves and Inscription of The Dutch Tomb in Kebon Jahe. Jurnal Kapata Arkeologi, Volume 14(Issue 1, July 2018,), 63-78.

Nuralia, L. dkk. (2019). Bangunan Industri dan Produksi Perkebunan Kina Kabupaten Bandung Barat dan Sekitarnya, Provinsi Jawa Barat, Abad XIX - XX Masehi.

Rusyanti. (2015). Kerkhoflaan Tanah Abang Jakarta: Interpretasi Menurut Michel Foucault. Jurnal Purbawidya, Vol. 4,(No, 1, Maret 2015.), Halaman 1-11.

Snelleman, J. F. (1905). Encyclopcedie van Nederlandsch-Indië, Jilid IV. Martinus Nijhoff.

Suratminto, L. (n.d.). Teks Pada Batu Nisan Baron Van Imhoff Diihat Melalui Analisis Semiosis Model Peirce dan Danesi-Perron. Jurnal Makara.Fakultas Ilmu Budaya Universitas Indonesia.

Susanti, Y. N. (2005). Antara Prasasti dan Naskah Sastra: Data Sejarah di Dalam Prasasti-Prasasti Airlangga dan Kakawin Arjunawiwaha. Makalah dalam Seminar Internasional Jawa Kuna Mengenang Jasa-Jasa Prof. Dr. P.J Zoetmoelder S.J.: Kajian Bahasa, Sastra, dan Budaya Sunda Kuna,.

Van Niel, R. (1988). Munculnya Elit Modern Indonesia. Pustaka Jaya. 